\title{
Perancangan Sistem Penentuan Objek Wisata di Bali Masa Pandemi COVID-19 dengan Metode Weighted Product yang Dimodifikasi
}

\section{Designing System for Determining Tourism Objects in Bali during the COVID-19 Pandemic with Modified Weighted Product Method}

I Nyoman Sweta

Badan Pusat Statistik Provinsi Bali, Indonesia

\section{Article Info}

\section{Article history:}

Received, 23 Maret 2021

Revised, 26 April 2021

Accepted, 29 April 2021

\section{Kata Kunci:}

Weighted Product

Pandemi COVID-19

Pariwsata Bali

New Normal

Keywords:

Weighted Product

Pandemic COVID-19

Bali Tourism

New Normal

\begin{abstract}
ABSTRAK
Pandemi COVID-19 memberikan dampak yang luar biasa terhadap perekonomian global termasuk Indonesia. Apalagi Bali yang sangat bergantung dari sektor pariwisata, salah satu sektor yang terkkena dampak langsung. Pada masa new normal, pemangku kepentingan mulai harus menyiapkan strategi untuk menentukan kembali beroperasionalnya sektor unggulan ini tanpa mengabaikan aspek kesehatan. Alat bantu diperlukan untuk bahan pertimbangan dalam mengambil kebijakan nantinya. Weighted Product merupakan salah satu cara pengambilan keputusan dalam menentukan alternatif terbaik berdasarkan beberapa kriteria yang ada. Untuk mengantisipasi kebijakan masa pandemi, diperlukan melakukan modifikasi terhadap metode Weighted Product. Berdasarkan hal tersebut, maka dilakukan penelitian dengan judul "Perancangan Sistem Penentuan Objek Wisata di Bali Masa Pandemi COVID-19 dengan Metode Weighted Product yang Dimodifikasi". Sistem yang dikembangkan sudah diuji dengan pengujian black box untuk memastikan sistem berjalan sesuai dengan yang diinginkan. Hasil dari penelitian ini berupa Sistem Penunjang Keputusan dalam penentuan objek wisata yang layak dikunjungi pada masa Pandemi COVID-19. Sehingga bisa menjadi salah satu alat bantu untuk pemerintah daerah Provinsi Bali dalam mengambil kebijakan terkait sektor pariwisata.
\end{abstract}

\section{ABSTRACT}

The COVID-19 pandemic has had a tremendous impact on the global economy, including Indonesia. Moreover, Bali is very dependent on the tourism sector, one of the sectors that is directly affected. During the new normal period, stakeholders began to prepare strategies to determine the return to operation of this superior sector without neglecting the health aspect. Assistive tools are needed for consideration in making policies later. Weighted Product is a way of making decisions in determining the best alternative based on several existing criteria. To anticipate the policy during a pandemic, it is necessary to make modifications to the Weighted Product method. Based on this, a research was conducted with the title "Designing a Tourism Object Determination System in Bali during the COVID-19 Pandemic with a Modified Weighted Product Method". The system developed has been tested with black box testing to ensure the system runs as desired. The results of this study are in the form of a Decision Support System in determining tourist objects worth visiting during the COVID19 Pandemic. So that it can be a tool for the local government of Bali Province in making policies related to the tourism sector.

This is an open access article under the CC BY-SAlicense.

\section{Penulis Korespondensi:}

I Nyoman Sweta,

Pranata Ahli Komputer Pertama,

Badan Pusat Statistik Provinsi Bali,

Email: sweta@bps.go.id 


\section{PENDAHULUAN}

Penelitian ini bertujuan untuk memberikan solusi berupa Sistem Pendukung Keputusan (SPK) yang memberikan rekomendasi obyek wisata layak dibuka pada masa pandemi COVID-19 dengan metode Weighted Product yang dimodifikasi kepada pemangku kepentingan di provinsi Bali. Penelitian ini diambil untuk mendukung upaya pemerintah dalam pemulihan pariwisata [1]. Pandemi COVID-19 membawa dampak yang cukup besar bagi perekonomian global termasuk Indonesia khususnya pada sektor industri pariwisata, perdagangan dan investasi [2]. Demikian juga halnya dengan Bali yang sangat bergantung dari sektor pariwisata. BPS Provinsi Bali melaporkan bahwa perekonomian Bali tercatat mengalami kontraksi sedalam 12,28\% pada triwulan III tahun 2020. Ketergantungan pada sektor pariwisata sangat rentan terhadap berbagai fenomena global seperti isu kolera, perang, dan terkini pandemi COVID-19. Dampak dari peristiwa tersebut sangat terasa dan langsung mempengaruhi kondisi perekonomian di wilayah Bali [3]. Dampak pandemi COVID-19 ini tentu saja sangat dirasakan bagi tenaga kerja yang bekerja di sektor pariwisata dan sektor terkait lainnya. Sebanyak 71.313 pekerja sektor formal mengalami pemutusan hubungan kerja (PHK) [4]. Survei Angkatan Kerja Nasional 2020, mengungkap bahwa sekitar 24,69 persen penduduk usia kerja di Bali terdampak gejolak pandemi COVID-19. Diperkirakan 98,18 ribu orang menjadi pengangguran akibat situasi ini [5].

Sampai saat ini belum dapat dipastikan kapan pandemi ini akan berlalu. Demikian pula halnya dengan vaksin COVID-19 belum dapat tersedia dalam waktu dekat. Sementara ekonomi terap harus diselamatkan. Dengan berbagai pertimbangan tersebut, pemerintah mengambil kebijakan new normal tentunya tanpa mengabaikan apsek kesehatan [6]. Sejatinya pemerintah telah berupaya melakukan langkah-langkah untuk menyelamatkan dan meningkatkan laju ekonomi dalam sektor pariwisata. New normal tourism pada beberapa tempat telah dilakukan dengan tetap menerapkan protokol kesehatan, salah satunya di Bali [7]. Pemerintah Bali sangat serius menyongsong ini dengan mengeluarkan Surat Edaran (SE) Gubernur Bali Nomor 3355 Tahun 2020 tentang Penerapan Tatanan Kehidupan Era Baru [8]. Dalam upaya kebijakan new normal khususnya sektor pariwisata, maka pemangku kepentingan harus sudah menyiapkan destinasi obyek wisata yang siap dioperasikan. Kajian komprehensif mutlak diperlukan mengingat ini menyangkut kepentingan banyak hal. Salah satunya adalah mengunakan alat bantu berupa SPK.

Penelitian mengenai pemilihan tempat wisata dengan metode Weighted Product sudah pernah dilakukan seperti pada peneilitian [9]. Begitu juga dengan penelitian yang mengambil lokasi di Yogyakarta [10]. Selanjutnya penelitian untuk memilih wisata terfavorit di Nias Selatan[11]. Penelitan sebelumnya masih belum mengakomodasi kondisi pandemi COVID-19. Berangkat dari latar belakang tersebut, penelitian ini dilakukan bertujuan untuk memberikan solusi berupa SPK kepada pemangku kepentingan di provinsi Bali dengan memberikan rekomendasi objek wisata di Bali yang layak dibuka pada masa pandemi COVID-19 dengan menggunakan metode Weighted Product yang dimodifikasi menggunakan framework Laravel dan database MySql. Dalam pengujian sistem ini, data yang digunakan hanya contoh bukan data sebenarnya.

\section{METODE PENELITIAN}

Metodologi yang digunakan penulis dalam melakukan penelitian ini terdiri dari metode pengembangan sistem berupa model waterfall dan metode SPK yaitu metode Weighted Product.

\subsection{Metode Pengembangan Sistem}

Metode penelitian SPK ini menggunakan model waterfall, merupakan model pengembangan sistem yang sistematik dan runut [12]. Adapun tahapannya dapat dilihat pada Gambar 1.

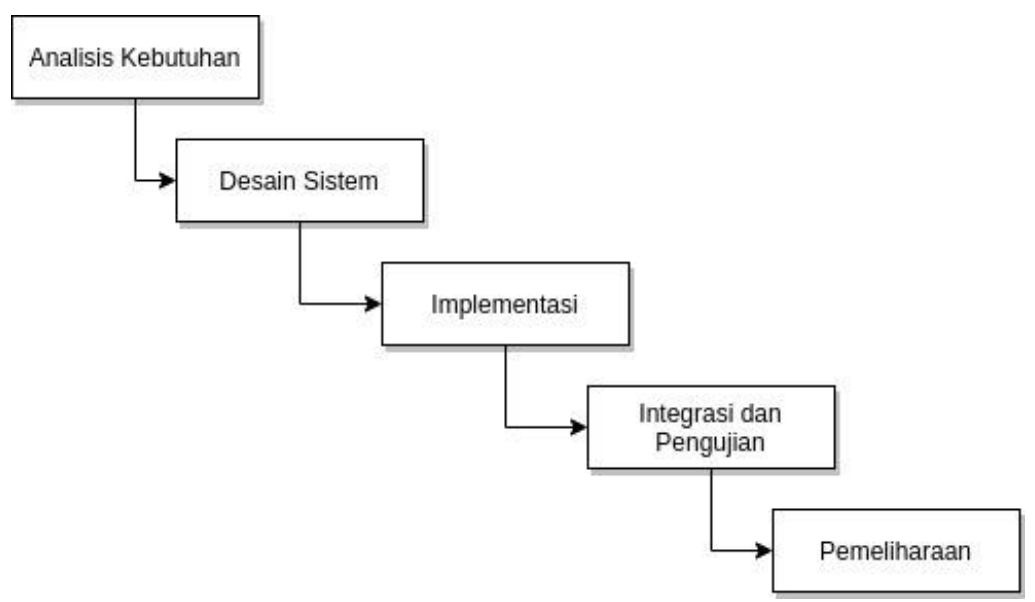

Gambar 1. Tahapan metode waterfall

Penjelasan dari metode waterfall adalah sebagai berikut [13]. Pada tahap analisis kebutuhan beberapa kriteria yang dibutuhkan dikumpulkan untuk menentukan kelayakan daerah obyek wisata untuk dikunjungi. Kriteria tidak dikumpulkan 
semua, karena dengan sistem yang dibuat kriteria untuk mendukung keputusan bisa ditambahkan secara dinamis. Berikutnya adalah tahapan pemilihan metode untuk membuat SPK ini. Dalam penelitian ini memilih metode Weighted Product yang dimodifikasi. Modifikasi dimaksudkan untuk menambah tahapan penentuan keputusan setelah perhitungan Weighted Product. Untuk membantu mendapatkan gambaran sistem yang dikembangkan, maka dibuatkan pemodelan berupa diagram use case.

Pada tahap implementasi dilakukan penerjemahan SPK ke dalam Laravel salah satu framework pada bahasa pemrograman PHP. Laravel digunakan untuk mengembangkan sebuah aplikasi dengan konsep model view controller (MVC), menyediakan sintak yang ekspresif, jelas serta menghemat waktu [14]. Seluruh unit yang dibangun kemudian diintegrasikan menjadi satu kesatuan pada sebuah sistem dan dilakukan pengujian. Tujuan dari pengujian ini adalah menguji apakah sistem yang sudah dibuat sesuai dengan kriteria-kriteria yang diinginkan.

\subsection{Metode Weighted Product}

Metode Weighted Product merupakan salah satu metode untuk menyelesaikan Multi Attribute Decision Making (MADM). Teknik yang digunakan dalam Weighted Product melakukan perkalian untuk menghubungkan rating atribut, dimana rating setiap atribut harus dipangkatkan terlebih dahulu dengan atribut bobot yang bersangkutan [15]. Proses perhitungan dengan metode Weighted Product terdiri dari beberapa langkah atau tahap. Langkah pertama adalah menentukan nilai bobot dari setiap kriteria (W). Pada perhitungan ini nilai $\mathrm{W}$ akan berada pada rentang dari 0 sampai dengan 1 . Dimana total nilai $\mathrm{W}$ adalah 1 . Untuk mendapatkan nilai normalisasi $\mathrm{Wj}$ dengan cara mengalikan atribut yang menguntungkan (benefit) dengan 1, sementara yang atribut bernilai biaya (cost) dikalikan dengan -1. Ada perhitungannya adalah dengan menggunakan rumus (1).

$$
W_{j}=\frac{W_{j}}{\sum W_{j}}
$$

Dengan $\mathrm{W}=$ bobot kriteria dan $\mathrm{j}=$ kriteria.

Berikutnya adalah langkah mencari hasil normalisasi dari setiap alternatif. Caranya dengan mengalikan seluruh kriteria bagi sebuah alternatif dengan bobot yang sudah dinormalisasi sebagai pangkat. Si adalah hasil normalisasi keputusan pada alternatif ke-i, Xij adalah rating alternatif per attribut, $\mathrm{i}$ adalah alternatif, $\mathrm{j}$ adalah atribut. Adapun perhitungannya adalah dengan rumus (2).

$$
S_{i}=\prod_{j=1}^{n} X_{i j}^{W_{j}}
$$

Dengan $\mathrm{S}=$ Preferensi alternatif dianologikan sebagai vektor, $\mathrm{X}=$ nilai kriteria, $\mathrm{i}=$ alternatif, dan $\mathrm{n}=$ banyaknya kriteria.

Terakhir adalah mencari hasil preferensi setiap alternatif $(V)$. Setelah nilai V didapatkan, maka diurutkan dari nilai terbesar. Nilai V terbesar merupakan alternatif terbaik. Nilai V didapatkan dengan menggunakan rumus (3).

$$
V_{i}=\frac{\prod_{j=1}^{n} X_{i j}^{W_{j}}}{\prod_{j=1}^{n} X_{i j} * W_{j}}
$$

Dengan V=preferensi setiap alternatif.

\section{HASIL DAN ANALISIS}

Modifikasi pada metode ini dimaksudkan untuk menambah tahapan penentuan keputusan yang tidak diperhitungkan setelah proses perhitungan Weighted Product. Pada perhitungan Weighted Product akan mendapatkan hasil berupa urutan terbesar dari sejumlah alternatif yang dalam hal ini adalah obyek wisata. Modifikasi metode dilakukan dengan menambahkan atribut kategori untuk mengelompokkan obyek wisata. Pada masa pandemi COVID-19 ini, otoritas tertinggi (pemerintah pusat) bisa saja mengeluarkan keputusan atau kebijaksanan yang bersifat mendadak terkait ijin operasional dunia usaha. Kebijakan tersebut misalnya mengatur kategori obyek wisata yang boleh dan tidak boleh dibuka pada masa pandemi. Jadi jika obyek wisata yang sudah disiapkan mendapatkan nilai tinggi sesuai metode Weighted Product, tetapi tidak termasuk kategori yang diijinkan beroperasional, maka tetap harus dieliminasi. Adapun gambaran dari modifikasi metode ini adalah seperti Gambar 2. 


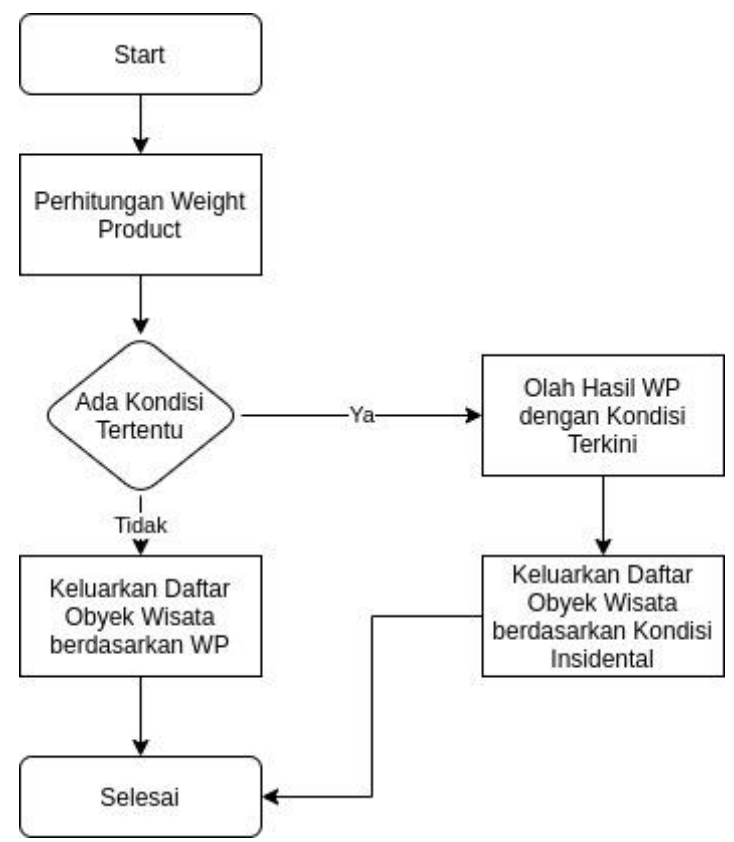

Gambar 2. Diagram alur modifkasi metode weighted product

\subsection{Perhitungan Weighted Product}

Kriteria yang dijadikan pertimbangan kelayakan obyek wisata untuk dikunjungi ditentukan oleh pemangku kepentingan berdasarkan berbagai pertimbangan. Kriteria bersifat dinamis dimana bisa ditambahkan atau dikurangi sesuai dengan kebutuhan pada penerapan suatu kasus. Bobot diisi dengan rentang angka dari 1 sampai 5, dimana semakin besar nilainya akan semakin bagus untuk kriteria dengan jenis benefit dan kurang bagus untuk jenis cost. Beberapa kriteria yang bisa dijadikan pertimbangan seperti ditunjukkan pada Tabel 1 .

Tabel 1. Daftar Kriteria

\begin{tabular}{|c|c|c|c|}
\hline Kode & Kriteria & Jenis & Bobot \\
\hline $\mathrm{C} 1$ & Penerapan protokol kesehatan COVID-19 & Benefit & 5 \\
\hline $\mathrm{C} 2$ & Penerapan Protokol Kesehatan COVID-19 masyarakat sekitar Obyek Wisata & Benefit & 4 \\
\hline $\mathrm{C} 3$ & Zona Wilayah (Tinggi=Merah) & Cost & 5 \\
\hline $\mathrm{C} 4$ & $\begin{array}{l}\text { Akomodasi dan Transportasi ke Obyek } \\
\text { Wisata }\end{array}$ & Benefit & 3 \\
\hline $\mathrm{C} 5$ & Sarana dan Prasarana & Benefit & 5 \\
\hline
\end{tabular}

Berdasakan daftar kriteria tersebut kemudian dilakukan perhitungan bobot. Untuk kriteria yang termasuk biaya, maka Wj ternomaliasi dikalikan -1, sedangan yang menguntungkan dikalikan 1 atau tetap, seperti terlihat pada Tabel 2.

Tabel 2. Normalisasi Bobot

\begin{tabular}{cccc}
\hline Kriteria & Wj & Jenis & Wj \\
\hline C1 & 0.23 & Benefit & 0.23 \\
C2 & 0.18 & Benefit & 0.18 \\
C3 & 0.23 & Cost & -0.23 \\
C4 & 0.14 & Benefit & 0.14 \\
C5 & 0.23 & Benefit & 0.23 \\
\hline
\end{tabular}

Langkah berikutnya adalah menentukan sejumlah alternatif dalam hal ini objek wisata yang akan dipilih untuk beroperasional. Keterangan kategori diperlukan untuk mengelompokkan objek wisata. Setelah perangkingan dengan Weighted Product, kategori menjadi penentu apakah objek wisata bisa beropersional atau tidak pada masa pandemi. Objek wisata yang dipersiapkan beroperasi pada masa new normal tourism seperti pada Tabel 3. 
Tabel 3. Daftar Alternatif

\begin{tabular}{cllc}
\hline Kode & Alternatif & Lokasi & Kategori \\
\hline OW1 & Objek Wisata 1 & Badung & A \\
OW2 & Objek Wisata 2 & Denpasar & B \\
OW3 & Objek Wisata 3 & Gianyar & C \\
OW4 & Objek Wisata 4 & Bangli & B \\
OW5 & Objek Wisata 5 & Tabanan & A \\
\hline
\end{tabular}

Pada langkah ini kita mengisikan nilai kriteria-kriteria dari setiap alternatif dengan rentang angka 1 sampai dengan 5. Semakin besar angkanya akan semakin bagus untuk kriteria dengan jenis benefit dan kurang bagus untuk kriteria dengan jenis cost. Adapun contoh pengisian data kriteria dapat kita lihat pada Tabel 4.

Tabel 4. Mengisi Nilai Kriteria

\begin{tabular}{cccccc}
\hline \multirow{2}{*}{ Alternatif } & \multicolumn{5}{c}{ Kriteria } \\
\cline { 2 - 6 } & C1 & C2 & C3 & $\mathbf{C 4}$ & $\mathbf{C 5}$ \\
\hline OW1 & 5 & 5 & 2 & 2 & 5 \\
OW2 & 5 & 5 & 3 & 5 & 5 \\
OW3 & 4 & 3 & 3 & 5 & 5 \\
OW4 & 3 & 5 & 4 & 4 & 5 \\
OW5 & 5 & 3 & 3 & 5 & 5 \\
\hline
\end{tabular}

Menghitung Si dilakukan setelah bobot normalisasi didapatkan. Adapun perhitungannya adalah seperti pada Tabel 5.

Tabel 5. Menghitung Preferensi

\begin{tabular}{ccccccc}
\hline Alternatif & $\mathbf{C 1} \mathbf{1}^{\wedge} \mathbf{W}$ & $\mathbf{C 2}{ }^{\wedge} \mathbf{W j}$ & $\mathbf{C} 3^{\wedge} \mathbf{W} \mathbf{j}$ & $\mathbf{C 4}^{\wedge} \mathbf{W} \mathbf{j}$ & $\mathbf{C 5}^{\wedge} \mathbf{W j}$ & $\mathbf{S i}$ \\
\hline OW1 & 1.44 & 1.34 & 0.85 & 1.10 & 1.44 & 2.61 \\
OW2 & 1.44 & 1.34 & 0.78 & 1.25 & 1.44 & 2.70 \\
OW3 & 1.37 & 1.22 & 0.78 & 1.25 & 1.44 & 2.34 \\
OW4 & 1.28 & 1.34 & 0.73 & 1.21 & 1.44 & 2.19 \\
OW5 & 1.44 & 1.22 & 0.78 & 1.25 & 1.44 & 2.46 \\
\hline
\end{tabular}

Menghitung nilai vektor dari setiap preferensi (Vi) adalah dengan membagis setiap preferensi dengan jumlah seluruh preferensi. Sehingga hasilnya dapat dilihat pada Tabel 6.

Tabel 6. Menghitung Nilai Vektor

\begin{tabular}{ccc}
\hline Alternatif & Nama Alternatif & Vi \\
\hline OW1 & Obyek Wisata 1 & 0.21 \\
OW2 & Obyek Wisata 2 & 0.22 \\
OW3 & Obyek Wisata 3 & 0.19 \\
OW4 & Obyek Wisata 4 & 0.18 \\
OW5 & Obyek Wisata 5 & 0.20 \\
\hline
\end{tabular}

Setelah hasil perhitungan vektor didapatkan, langkah selanjutnya adalah melakukan perangkingan dengan mengurutkan dari nilai terbesar. Adapun hasil dari perangkingan hasil metode Weighted Product dapat dilihat pada Tabel 7.

Tabel 7. Menentukan Peringkat

\begin{tabular}{ccccc}
\hline Peringkat & Alternatif & Nama Alternatif & Kategori & Vi \\
\hline 1 & OW2 & Obyek Wisata 2 & B & 0.22 \\
\hline 2 & OW1 & Obyek Wisata 1 & A & 0.21 \\
\hline 3 & OW5 & Obyek Wisata 5 & A & 0.20 \\
\hline 4 & OW3 & Obyek Wisata 3 & C & 0.19 \\
\hline 5 & OW4 & Obyek Wisata 4 & B & 0.18 \\
\hline
\end{tabular}

\subsection{Modifikasi}

Modifikasi metode ini dilakukan dengan menambahkan atribut kategori di alternatif. Atribut ini berfungsi untuk mengelompokan alternatif. Dimana hasil pengelompokkan itu menjadi penentu akhir boleh tidaknya alternatif pilihan beroperasi pada masa Pandemi. Pada langkah ini kategori obyek wisata dilakukan pemutakhiran sesuai kebijakan terkini dari otoritas yang berwenang. Adapun hasilnya dapat dilihat pada Tabel 8. 
Tabel 8. Menentukan Kategori

\begin{tabular}{clc}
\hline Kode & Nama Kategori & Ijin Operasi \\
\hline A & Kelompok Obyek Wisata A & Y \\
B & Kelompok Obyek Wisata B & N \\
C & Kelompok Obyek Wisata C & Y \\
D & Kelompok Obyek Wisata D & Y \\
\hline
\end{tabular}

Pada contoh Tabel 8, kategori yang tidak layak beroperasi adalah kategori B. Maka dilakukan proses eliminasi terhadap alternatif yang termasuk kategori B seperti pada Tabel 9.

Tabel 9. Eliminasi Alternatif

\begin{tabular}{ccccc}
\hline Peringkat & Nama Alternatif & Kategori & Vi & Final \\
\hline 1 & Obyek Wisata 2 & B & 0.22 & X \\
2 & Obyek Wisata 1 & A & 0.21 & 1 \\
3 & Obyek Wisata 5 & A & 0.2 & 2 \\
4 & Obyek Wisata 3 & C & 0.19 & 3 \\
5 & Obyek Wisata 4 & B & 0.18 & X \\
\hline
\end{tabular}

Setelah eliminasi dilakukan, maka akan didapatkan hasil akhir berupa perangkingan metode Weighted Product dengan mengeliminasi alternatif yang tidak diijinkan beroperasi. Sehingga hasil akhirnya adalah seperti pada Tabel 10.

Tabel 10. Peringkat Akhir Setelah Modifikasi

\begin{tabular}{ccccc}
\hline Peringkat & Nama Alternatif & Kategori & Vi & Final \\
\hline 1 & Obyek Wisata 1 & A & 0.21 & 1 \\
2 & Obyek Wisata 5 & A & 0.2 & 2 \\
3 & Obyek Wisata 3 & C & 0.19 & 3 \\
\hline
\end{tabular}

\subsection{Diagram Use Case}

Diagram use case dibuat untuk menganalisa kebutuhan dan mengetahui interaksi antara aktor dengan sistem. Aktor yang terlibat dalam sistem adalah Administrator, Operator dan Pemangku Kepentingan. Administrator bertugas untuk mengelola pengguna sistem. Operator bertugas untuk mengelola alternatif, kriteria dan melakukan perhitungan untuk memproleh daftar rangking alternatif. Sedangkan Pemangku Kepentingan melihat hasil perhitungan untuk dijadikan dalam menentukan keputusan operasional usaha obyek wisata. Hubungan antara aktor dan sistem dapat kita lihat pada Gambar 3.

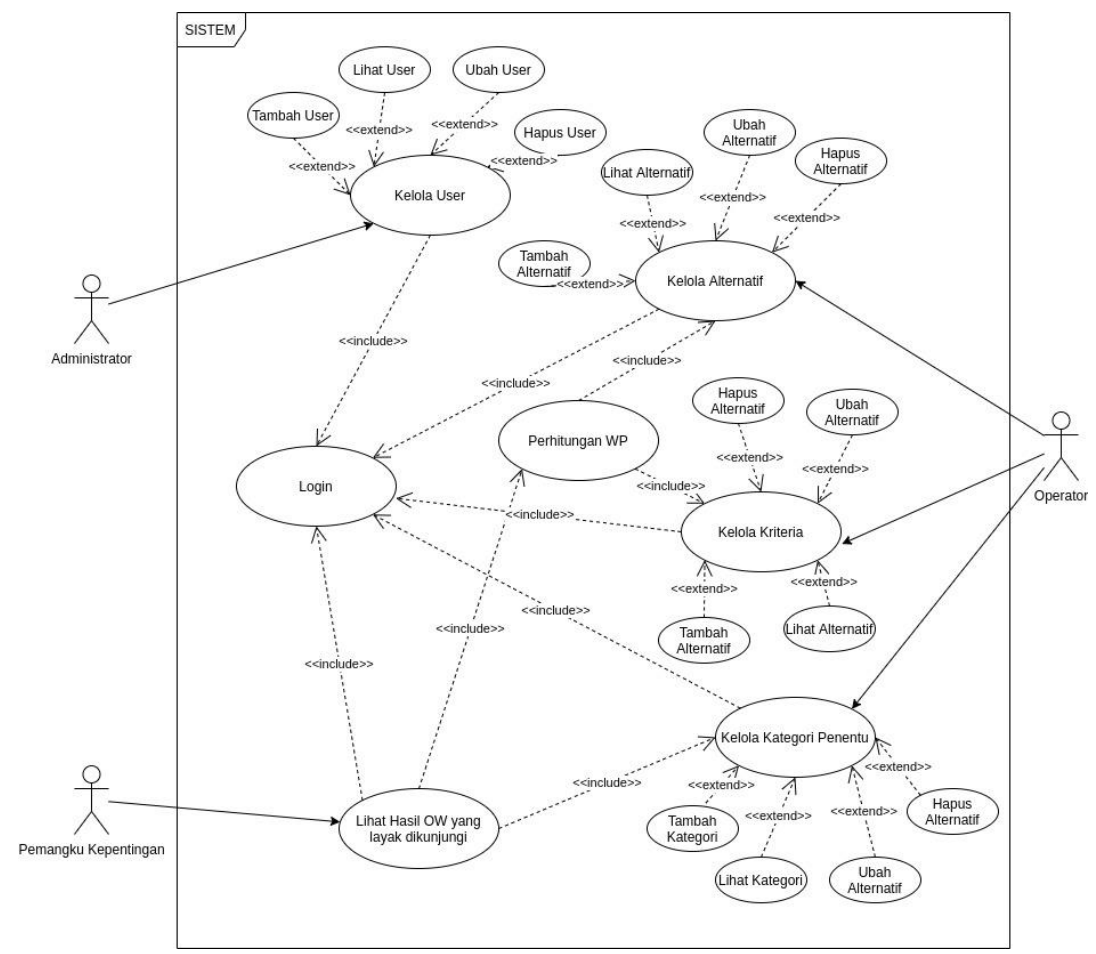

Gambar 3. Diagram use case system 


\subsection{Implementasi}

Implementasi penelitian "Menentukan Objek Wisata di Bali Masa Pandemi COVID-19 dengan Metode Weighted Product yang Dimodifikasi" ini menggunakan framework Laravel dan database MySql. Sementara untuk kenyamanan pengguna dan user friendly, implementasi tampilan menggunakan framework Bootstrap [16]. Pada perhitungan dengan metode Weighted Product, kriteria yang diperlukan untuk mengambil keputusan bersifat dinamis. Kriteria dan bobot bisa diatur sesuai degan kebutuhan. Adapun tampilan untuk mengelola daftar kriteria dan bobot seperti pada Gambar 4.

Data Kriteria
Kata Kunci

\section{Q Cari}

\section{() Input Kriteria Baru}

\begin{tabular}{|c|c|c|c|c|c|c|}
\hline \# & Kode Kriteria & Nama Kriteria & Jenis & Bobot & Aksi & \\
\hline 1 & $\mathrm{C} 1$ & Penerapan Protokol Kesehatan COVID-19 & Benefit & 5 & $\widetilde{Z}$ Edit & 囬 Hapus \\
\hline 2 & $\mathrm{C} 2$ & Penerapan Protokol Kesehatan COVID-19 masyarakat sekitar Obyek Wisata & Benefit & 4 & $\widetilde{C}$ Edit & 角 Hapus \\
\hline 3 & C3 & Zona Wilayah (Tinggi=Merah) & Cost & 5 & $\mathbb{Z}$ Edit & 面 Hapus \\
\hline 4 & C4 & Akomodasi dan Transportasi ke Obyek Wisata & Benefit & 3 & $\mathbb{Z}$ Edit & 面 Hapus \\
\hline 5 & $\mathrm{C} 4$ & Sarana dan Prasarana & Benefit & 5 & $\mathbb{Z}$ Edit & 面 Hapus \\
\hline
\end{tabular}

Gambar 4. Daftar Kriteria

Berikutnya adalah mengelola alternatif yang dalam kasus penelitian ini adalah daerah obyek wisata. Pada halaman ini disedikan menu untuk menambah, melihat, mengubah dan menghapus alternatif sebagaimana terlihat pada Gambar 5.

\section{Data Obyek Wisata (Alternatif)}

\begin{tabular}{|c|c|c|c|c|c|c|}
\hline \multicolumn{7}{|c|}{ Kata Kunci } \\
\hline \multicolumn{7}{|c|}{ Q Cari } \\
\hline & & & & & & (†) Input \\
\hline \# & Kode & Nama Obyek Wisata (Alternatif) & Kategori & Lokasi & Aksi & \\
\hline 1 & ow1 & Obyek Wisata 1 & A & Denpasar & $\boldsymbol{E}$ Edit & 向 Hapus \\
\hline 2 & ow2 & Obyek Wisata 2 & B & Badung & $\boldsymbol{Z}$ Edit & 向 Hapus \\
\hline 3 & ow3 & Obyek Wisata 3 & C & Bangli & $\boldsymbol{Z}$ Edit & 向 Hapus \\
\hline 4 & ow4 & Obyek Wisata 4 & B & Bangli & $\mathbb{E}$ Edit & 包 Hapus \\
\hline 5 & ow5 & Obyek Wisata 5 & C & Karangasem & $\boldsymbol{Z}$ Edit & 命 Hapus \\
\hline
\end{tabular}

Gambar 5. Daftar Alternatif 
Untuk mengisi nilai kriteria dari setiap alternatif dapat dilihat seperti pada Gambar 6.

\section{Edit Data Obyek Wisata (Alternatif)}

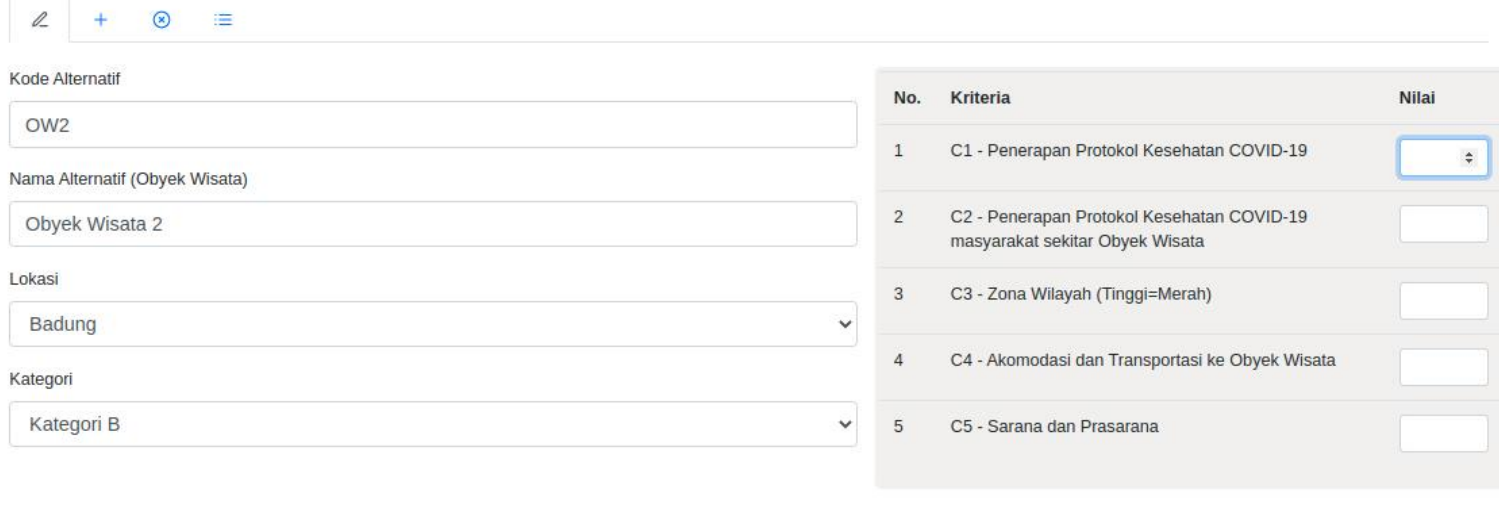

Gambar 6. Mengisi nilai kriteria

Hasil perhitungan bobot dan preferensi alternatif ditampilkan pada Gambar 7.

\section{Perhitungan Bobot Ternormalisasi}

\begin{tabular}{llll} 
Kriteria & Wj & Jenis & Wj ternormalisasi \\
\hline C1 & 0.227 & Benefit & 0.227 \\
\hline C2 & 0.182 & Benefit & 0.182 \\
\hline C3 & 0.227 & Cost & -0.227 \\
\hline C4 & 0.136 & Benefit & 0.136 \\
\hline C5 & 0.227 & Benefit & 0.227
\end{tabular}

\section{Mencari Nilai Si}

\begin{tabular}{|c|c|c|c|c|c|c|}
\hline Alternatif & $C 1^{\wedge} W j$ & $C 2^{\wedge} W_{j}$ & $C 3^{\wedge} W j$ & $\mathrm{C}^{\wedge} \mathrm{WWj}^{-}$ & $C 5^{\wedge} W \mathrm{j}$ & Si \\
\hline ow1 & 1.4416 & 1.3399 & 0.8542 & 1.0991 & 1.4416 & 2.6148 \\
\hline ow2 & 1.4416 & 1.3399 & 0.7790 & 1.2454 & 1.4416 & 2.7019 \\
\hline ow3 & 1.3704 & 1.2211 & 0.7790 & 1.2454 & 1.4416 & 2.3405 \\
\hline OW4 & 1.2836 & 1.3399 & 0.7297 & 1.2081 & 1.4416 & 2.1860 \\
\hline ow5 & 1.4416 & 1.2211 & 0.7790 & 1.2454 & 1.4416 & 2.4623 \\
\hline
\end{tabular}

Gambar 7. Daftar Alternatif

Hasil akhir perhitungan dengan weighted product adalah berupa perangkingan dari setiap alternatif yang tersedia. Berikut ini adalah tampilan rangking dan grafik batang seperti pada Gambar 8 . 


\begin{tabular}{llll}
\multicolumn{2}{l}{ Peringkat Berdasarkan } & WP & \\
\hline Peringkat & Alternatif & Nama Alternatif & Vi \\
\hline 1 & OW2 & Obyek Wisata 2 & 0.2196 \\
\hline 2 & OW1 & Obyek Wisata 1 & 0.2125 \\
\hline 3 & ow5 & obyek Wisata 5 & 0.2001 \\
\hline 4 & ow3 & obyek Wisata 3 & 0.1902 \\
\hline 5 & OW4 & Obyek Wisata 4 & 0.1776
\end{tabular}

\section{Rangking}

Hasil Perhitungan WP

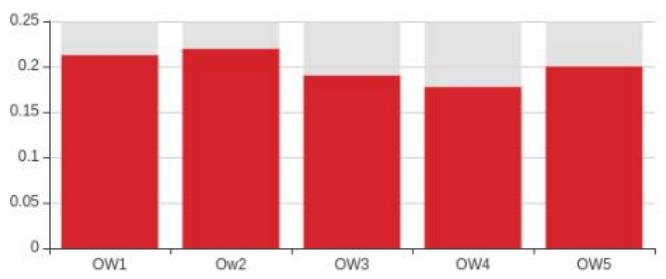

Gambar 8. Perhitungan bobo dan preferensi alternatif

Modifikasi pada metode Weighted Product pada penelitian ini adalah dengan menambahkan atribut kategori pada alternatif. Kategori ini untuk menentukan proses eliminasi alternatif. Ada kemungkinan alternatif yang hasil rangking perhitungan metode Weighted Product bagus, tapi tereliminasi oleh kategori alternatifnya. Proses eliminasi bisa dilihat pada Gambar 9.

Tabel ljin Operasional Wisata

\begin{tabular}{llll} 
No & Kode & Nama Kategori & Status Ijin \\
\hline 1 & A & Kelompok Obyek Wisata A & Y \\
\hline 1 & B & Kelompok Obyek Wisata B & N \\
\hline 1 & C & Kelompok Obyek Wisata C & Y \\
\hline 1 & D & Kelompok Obyek Wisata D & Y
\end{tabular}

\section{Eliminasi Berdasarkan Kategori}

\begin{tabular}{llllll}
\hline Peringkat & Alternatif & Nama Alternatif & Kategori & Vi & Final \\
\hline 1 & OW2 & Obyek Wisata 2 & B & 0.22 & X \\
\hline 2 & OW1 & Obyek Wisata 1 & A & 0.21 & 1 \\
\hline 3 & OW5 & Obyek Wisata 5 & A & 0.20 & 2 \\
\hline 4 & OW3 & Obyek Wisata 3 & C & 0.19 & 3 \\
\hline 5 & OW4 & Obyek Wisata 4 & B & 0.18 & X
\end{tabular}

Gambar 9. Hasil perhitungan metode weighted product

Pada penelitian sejenis sebelumnya yang menghasilkan perangkingan sesuai dengan kriteria yang ditetapkan, hasil akhir dari penelitian ini adalah perangkingan alternatif terbaik dengan melewati proses perhitungan Weighted Product yang sudah dimodifikasi. Adapun tampilannya adalah seperti pada Gambar 10.

\section{Hasil Akhir Perhitungan Obyek Wisata Yang Layak Dikunjungi}

\begin{tabular}{|c|c|c|c|c|c|}
\hline Peringkat & Alternatif & Nama Alternatif & Kategori & Vi & Final \\
\hline 1 & ow1 & Obyek Wisata 1 & A & 0.21 & 1 \\
\hline 2 & ow5 & Obyek Wisata 5 & A & 0.20 & 2 \\
\hline 3 & ow3 & Obyek Wisata 3 & c & 0.19 & 3 \\
\hline
\end{tabular}

Gambar 10. Proses eliminasi alternative 


\subsection{Pengujian Black Box}

Metode pengujian sistem menggunakan black box. Pengujian dilakukan pada setiap tampilan. Pengujian dilakukan untuk mengetahui apakah modul-modul yang digunakan pada sistem ini telah berfungsi dengan baik, seperti terlihat pada Tabel 11 .

Tabel 11. Uji Black Box

\begin{tabular}{|c|c|c|c|c|}
\hline No & Skenario & Hasil yang diharapkan & Pengguna & Hasil \\
\hline 1 & Pengujian modul Kelola User & $\begin{array}{l}\text { Proses tambah, edit, lihat, hapus data pengguna } \\
\text { berjalan. }\end{array}$ & Administrator & Sukses \\
\hline 2 & Pengujian modul Kelola Alternatif & $\begin{array}{l}\text { Proses tambah, edit, lihat, hapus data alternatif } \\
\text { berjalan. }\end{array}$ & Operator & Sukses \\
\hline 3 & Pengujian modul Kelola Kriteria & Proses tambah, edit, lihat, hapus data kriteria berjalan. & Operator & Sukses \\
\hline 4 & Pengujian modul Kelola Kategori & Proses tambah, edit, lihat, hapus data kategori berjalan. & Operator & Sukses \\
\hline 5 & Proses Weight Product & $\begin{array}{l}\text { Sistem melakukan proses perhitungan Weight Product } \\
\text { yang dimodifikasi }\end{array}$ & Operator & Sukses \\
\hline 6 & Pengujian Laporan Weight Product & $\begin{array}{l}\text { Sistem menampilkan laporan perhitungan Weight } \\
\text { Product yang dimodifikasi }\end{array}$ & $\begin{array}{l}\text { Pemangku } \\
\text { Kepentingan }\end{array}$ & Suskes \\
\hline
\end{tabular}

\subsection{Pengujian Hasil}

Berikutnya adalah pengujian hasil perhitungan metode yang digunakan. Pertama dilakukan pengujian metode Weighted Product dengan cara membandingkan perhitungan manual dengan alat bantu software libreoffice spreedsheet di sistem operasi Linux dengan perhitungan oleh sistem yang dikembangkan. Berikutnya dilanjutkan dengan perbandingan hasil proses eliminasi dengan metode yang sudah dimodifikasi. Hasil pengujiannya dapat dilihat pada Tabel 12.

Tabel 12. Perbandingan Hasil

\begin{tabular}{clc}
\hline \multirow{2}{*}{ No } & \multicolumn{1}{c}{ Item Yang diujikan } & $\begin{array}{c}\text { Perbandingan perhitungan manual dengan } \\
\text { sistem }\end{array}$ \\
\hline 1 & Perhitungan Weight Product & Sama \\
2 & Proses Modifikasi Metode Weight Product & Sama \\
\hline
\end{tabular}

\section{KESIMPULAN}

Setelah dilakukannya perancangan, implementasi serta pengujian pada sistem pendukung keputusan ini, maka dapat diperoleh beberapa kesimpulan. Penggunaan metode weighted product memberikan kemudahan bagi pengguna, pemangku kebijakan dan perancang sistem dalam memahami proses pergitungan nilai vektor dan perangkingan karena menggunakan formula yang relatif sederhana. Selain itu, adanya modifikasi metode weighted product semakin memeberikan fleksibilitas bagi pemangku kebijakan dalam penentuan objek wisata yang layak. Berdasarkan pengujian black box dan perhitungan hasil, sistem berjalan sudah sesuai dengan yang diharapkan, sehingga layak untuk dimplementasikan dalam mendukung kebijakan penentuan objek wisata layak dikunjungi pada masa pandemi COVID-19. Adapun saran yang dapat diberikan kepada penelitian lanjutan adalah dengan menambahkan lebih dari satu kategori pada setiap alternatif. Dengan demikian pengelompokkan alternatif menjadi lebih fleksibel.

\section{UCAPAN TERIMA KASIH}

Terima kasih kepada Bapak I Made Sukarsa, Bapak Endan Suwandana, Ibu Yulia Virantina, Bapak Novianto Budi Kurniawan, Bapak Utama Andri Arjita, atas masukkannya yang sangat berharga. Terima kasih pula kepada Bapak I Gede Heprin Prayasta, Bapak Taly Parwa, Ibu Putu Galuh Ika Safitri atas koreksi dan sarannya terhadap penelitian ini.

\section{REFERENSI}

[1] “Bali Siapkan Langkah Sambut Pariwisata New Normal,” Media Indonesia, 2020. .

[2] D. A. D. Nasution, E. Erlina, and I. Muda, "Dampak Pandemi COVID-19 terhadap Perekonomian Indonesia," Jurnal Benefita, vol. 5, no. 2, p. $212,2020$.

[3] T. T. Mihaela Rus, Mihaela Luminița Sandu, "The relationship between personality traits, values and interests in adolescents," Technium Social Sciences Journal, vol. 11, no. 1, pp. 591-601, 2020.

[4] “Anjloknya Sektor Pariwisata Bali, Puluhan Ribu NAKER Sektor Formal alami PHK,” Bali Post, 2020. .

[5] "Berita Resmi Statistik Keadaan Ketenagakerjaan Provinsi Bali No. 69/11/51/Th. XIV, 5 November 2020,” 2020. . 
[6] Widayatun, "Menyongsong Era New Normal Dalam Situasi Pandemi Covid -19: Momentum Peningkatkan Peran Keluarga Sebagai Agen Perubahan," LIPI, 2020. .

[7] A. Maharani and F. Mahalika, "New Normal Tourism Sebagai Pendukung Ketahanan Ekonomi Nasional Pada Masa Pandemi ( New Normal Tourism As a Support of National Economic Resistance in the Pandemic Period )," Jurnal Kajian LEMHANNAS RI, vol. 8, no. 2, pp. 43-56, 2020.

[8] I. D. G. Kusuma, “Wacana Pariwisata Bali Dalam Pusaran Pandemi Covid-19,” Jurnal Ilmiah Cakrawarti, vol. 3, no. 2, pp. 40-47, Aug. 2020 .

[9] A. K. Wardhani and A. Anindyaputri, "Sistem Informasi Pemilihan Tempat Wisata Menggunakan Metode Weighted Product," IJTIS: Indonesian Journal of Technology, Informatics and Science, vol. 2, no. 1, pp. 27-32, 2020.

[10] A. S. Honggowibowo, A. Pujiastuti, and S. Suryanto, "Sistem Pendukung Keputusan Pemilihan Destinasi Wisata Favorit Di Propinsi Yogyakarta Dengan Metode Weighted Product (Wp) Berbasis Android,” Compiler, vol. 6, no. 2, pp. 58-68, 2017.

[11] E. A. Giawa and Z. A. Matondang, "Sistem Pendukung Keputusan Penentuan Tempat Wisata Terfavorit Di Nias Selatan Dengan Metode Weighted Product (Wp),” PITIN: Publikasi Ilmiah Teknologi Informasi Neumann, vol. 3, no. 1, pp. 77-80, 2018.

[12] P. Roger S., Rekayasa Perangkat Lunak: Pendekatan Praktisi (Buku Dua). Yogyakarta: Andi, 2002.

[13] I. Sommerville, Software Engineering (9th Edition). USA: Addison-Wesley, 2011.

[14] Y. Supardi and Sulaeman, Y. Supardi and Sulaeman, Semua Bisa Menjadi Programmer Laravel Basic. Jakarta: PT Elex Media Komputindo, 2019.

[15] S. Kusumadewi, S. Hartati, and R. Wardoyo, Fuzzy MultiAtributeDecition Making (Fuzzy MADM). Yogyakarta: Graha Ilmu, 2006.

[16] M. F. Santoso, “Teknik Responsive Web Design Bootstrap 4 Serta Penerapannya Dalam Rancang Bangun Layout Web,” Jurnal Pilar Nusa Mandiri, vol. 15, no. 1, pp. 61-68, 2019. 
Matrik : Jurnal Manajemen, Teknik Informatika, dan Rekayasa Komputer,

Vol. 20, No. 2, Mei 2021: 367 378 